\title{
對〈新興人體胚胎研究技術、
}

\section{十四天規則和胚胎的特殊地位 $\rangle$}

\section{一文的回應}

\section{A Response to "Emerging}

\section{Human Embryo Research}

\section{Technologies, the 14-day Rule,}

\section{and the Special Status of the}

\section{Embryo"}

郭玉宇張雪塋

Guo Yuyu and Zhang Xueying

\footnotetext{
郭玉宇, 南京醫科大學馬克思主義學院副教授, 中國南京, 郵編 : 211166。

Guo Yuyu, Associate Professor, School of Marxism, Nanjing Medical University, Nanjing, China, 211166.

張雪瑩, 南京醫科大學馬克思主義學院碩士研究生, 中國南京, 郵編：211166。 Zhang Xueying, Postgraduate Student, School of Marxism, Nanjing Medical University, Nanjing, China, 211166.
}

《中外醫學哲學》XIX:2 (2021 年) : 頁 59-63。

International Journal of Chinese \& Comparative Philosophy of Medicine 19:2 (2021), pp. 59-63.

(c) Copyright 2021 by Global Scholarly Publications. 


\section{Abstract}

This paper responds to "Emerging Human Embryo Research Technologies, the 14-Day Rule, and the Special Status of the Embryo" by analyzing the moral status of the embryo. We hold that the embryo has a limited moral status that is influenced by local ethical and cultural factors. The moral status of the embryo can be evaluated according to its potential value to and relationship with society within the specific ethical and cultural context. On whether the embryo should be used in research, we recommend that researchers follow the principle of permission, i.e., seek consent from the agents who best represent the interests of the embryo (usually the parents).

Kirstin R.W. Matthews, Sam Lowe 和 Ana S. Iltis (馬修斯、洛 伊、伊爾蒂斯 2021) 一文主要批判國際幹細胞研究學會 (ISSCR) 2021 年所制定的關於胚胎研究的相關檔, 質疑新規定放寬了原有 對人類胚胎研究的 14 天限制, 原因是其沒有通過倫理程式, 而根 本原因是該學會在修改相關規定時回避了對於胚胎特殊地位的研 究。

本文認可作者的基本觀點, 即對於胚胎的認識涉及到形而上 學、倫理學和政治哲學的基本哲學問題。人類胚胎是什麼? 並非 從醫學上可以得到全面的答案, 而是給出一個是否是道德主體的 直接回應 (馬修斯、洛伊、伊爾蒂斯 2021)。也正如作者所認為的 如果取消 14 天的限制, 應該來自研究的實際需要, 同時需要道德 層面的支援。國際幹細胞研究學會 (ISSCR) 新規定, 明顯基於對 更多科學知識和治療可能性的期望, 卻缺乏道德層面的有力論 證。筆者支持作者對於胚胎研究的基本態度, 如應直面胚胎的道 德主體問題, 但是更強調在全球道德多元化背景下具體倫理規則 的制定還是要訴諸特定的共同體倫理文化。

人類胚胎是道德主體，代表著西方基督教傳統文化的一種整 體性看法, 理論的起點就是認為胚胎是位格人 (Humanperson), 具 
有完整的道德地位。區別表現在“位格人”形成階段的差異, 不 應該把已經定性為“位格人”的胚胎作為工具、手段來使用。

西方哲學也有從人的心智性去界定人的位格性的思想傳統， 從而將胚胎排除在位格人的範疇之外。笛卡爾的 “我思故我在” 的理論預設了“自我”有思考功能。辛格以是否擁有意識為標準 將生命分成三類: 第一類, 無意識的生命。第二類, 有意識的生 命, 但沒有自我意識。第三類, 有自我意識的生命。有自我意識 的生命的載體便是人 (Person)。(辛格 2005)

中國傳統文化中幾乎沒有對什麼是人（道德主體）有明確概 念上的界定。“人”的含義可分為：生物學意義上的生命、人的 身份的確立以及具有道德地位這三種不同的存在狀態。中國傳統 文化中 “落地為生” 的傳統道德觀幾乎沒有賦予胈胎本身的道德 權利, 中國文化中, 中國人對於胚胎的處理包括人工流產與用於 研究持一種寬容的態度, 更傾向於取決於父母的意願。

胚胎的特殊性在於其有著“有限道德地位”。“胚胎”屬於 一種非人的人類, 不是完整的人, 但在不同的文化背景裡, 它呈 現出不同程度的道德地位。

相對於西方傳統意識性哲學, 中國傳統哲學其本質為身體性 哲學。“什麼是中國傳統哲學自身特有的屬性? 顯而易見，這就 是中國哲學之根深蒂固的 '身體性”。這種 “身體性”表現為中 國古人一切哲學意味的思考無不與身體有關, 無不圍繞著身體來 進行, 還表現為也正是從身體出發而非從意識出發, 中國古人才 為自己構建了一種自成一體, 並有別於西方意識哲學的不無自覺 的哲學理論系統（張再林 2008）。”中國本土傳統倫理文化的身 體性也體現在對於胚胎是不是人 (有沒有道德地位) 的問題上, 註定了身體的 “落地為生”, 由此胈胎向身體轉型, 以身體面向 世界, 構建以身體為核心的社會關係。身體是起點和支點。一方 面, 宇宙萬物被視為由我身體生命顯發出的器用, 另一方面, 天 下眾生被視為我身體生命的擴展和延伸, 從而圍繞身體形成層層 
倫理關係（張再林 2006）。《論語》謂 “四海之內皆兄弟也”; 王陽明《大學問》稱 “間形骸而分爾我者, 小人矣” 以及王夫之 《經義》曰 “君子視天下猶吾耳目手足爾” 等等無一不是在表達 身體的器用以及圍繞身體形成的層層倫理關係。

胚胎只是生物學意義上的生命體，不是真正意義上的“人” 或者 “身體”，所以不是完全意義上的道德主體。但是它屬於特 殊的非人, 具有一定的道德地位。胚胎的有限道德地位體現在它 在特定文化背景下成為人的潛能性和對現實人的關係性價值。

首先, 應以特徵可能出現的潛能去界定人, 大可不必對潛能 性構成一條中間路線（如 14 天），儘量淡化胚胎的道德地位與其 發育過程的必然聯繫。中國傳統倫理文化背景下，胚胎的有限道 德地位體現在它從胚胎走向身體的潛能性, 需要憑藉生理、心理 以及社會關係的發展而確定。

其次, 關聯式價值並非工具性價值, 體現出對於他人的意義 層面。在中國傳統文化視域下, 很多時候不是通過強調胚胎的道 德地位和絕對價值來選擇處理方式, 而是根據胚胎對於現實相關 利益者的現實意義和人道主義。當然這並不意味著可以隨意處置 胚胎, 我們對胚胎應予足夠的尊重。在胚胎處於非人狀態下的特 殊情境, 關於胚胎的一切處理, 包括是否可以用於研究的處理, 建議遵循徵求最能代表胚胎利益的代理人 (一般為父母) 同意的 允許原則（恩格爾哈特 $2006 ， 124 ）$ 來決定選擇。

高新生命科學技術發展背景下, 生命倫理問題往往可以追溯 到道德主體的討論, 而後現代道德多元化社會裡, 尊重寬容以及 允許原則是必要的。面對中國生命倫理學領域的道德爭議, 我們 也應該結合中國的倫理文化語境去探討、去規範。 


\section{參考文獻 References}

馬修斯、洛伊、伊爾带斯：〈新興人體肧胎研究技術、十四天規則和胚 胎的特殊地位〉, 《中外醫學哲學》, 2021 年, 第 XIX 卷, 第 2 期, 頁 11-45 Kirstin R.W. Matthews, Sam Lowe and Ana S. Iltis. "Emerging Human Embryo Research Technologies, the 14-day Rule, and the Special Status of the Embryo," International Journal of Chinese \& Comparative Philosophy of Medicine, Vol. 19, No. 2, 2021, pp. 11-45.

辛格, 劉莘譯: 〈實踐倫理學〉, 上海: 東方出版社, 2005 。Peter Singer. Practical Ethics, translated by LIU Shen (Shanghai: Oriental Publishing, 2005).

恩格爾哈特, 范瑞平譯：〈生命倫理學基礎（第二版）〉, 北京：北京 大學出版社, 2006。H.T. Engelhardt. The Foundations of Bioethics, translated by FAN Ruiping (Beijing: Peking University Press, 2006).

張再林：〈中國古代倫理學的身體性〉, 《陝西師範大學學報》, 2006

年, 第 35 卷, 第 5 期, 真 64 。ZHANG Zailin. “On the Physical Connotation of Ancient Ethics in China," Journal of Shaanxi Normal University (Philosophy and Social Sciences Edition) , Vol. 35, No. 05, 2006, p.64.

張再林：〈走向 “身體哲學”-—國傳統哲學研究範式的變革〉, 《江 蘇社會科學》’2008 年, 第3 期, 頁 24。ZHANG Zailin. “Tending towards

'Body Philosophy' — Transformation of the Traditional Chinese Philosophical Research Paradigms," Jiangsu Social Science, No. 3, 2008, p. 24. 